\title{
Does Time Matter? - A Study of Participation of Women in Urban Governance
}

Riya Banerjee ${ }^{+}$

\section{Abstract}

Time is an important aspect of present day life. Everyone tries to manage time in their daily lives, but women often face many hurdles in this respect. They work in their homes as well as in the public sphere, which doubles their actual workload. Their responsibilities increase further when women are engaged in the field of governance as local representatives. The work of a local representative is considered as a $24 \times 7$ thankless job in the Indian context, and women councillors (WCs) have to work just as hard as the men. However, in the domestic sphere, because of gendered nature of household chores, women still tend to do more work than men. Due to this reason, women have to manage their time in order to provide better services to the citizens and ensure that their household duties are completed flawlessly. This paper raises the issues related to such management of time by the elected women in the urban governance of West Bengal. The issues are: first, the duration of work as a councillor and its relation with the honorarium they receive; second, the extent to which their household work hinders their path to creating their identity in urban governance; and third, the degree to which these two activities influence the quality of their leisure time. In 1995, United Nations Development Programme (UNDP) developed a methodology to analyse the value of time based on the time-use activities. This research underpins this methodology to justify the unpaid and underpaid work of the WCs as well as their management of time between indoor and outdoor activities. The primary data was collected by conducting individual interviews with 38 women councillors in the four selected small cities (Darjeeling, Balurghat, Raniganj and Chinsurah) of West Bengal.

Key words: Time-use activities, United Nations Development Programme (UNDP), Women Councillors, Gender Discrimination, Governance, interviews, unpaid and underpaid, small cities, West Bengal, India

\footnotetext{
${ }^{\dagger}$ Research Scholar (UGC), The University of Burdwan, Email: riyabanerjee084@gmail.com (C) 2017 Banerjee. This is an Open Access article distributed under the terms of the Creative Commons Attribution License (http://creativecommons.org/licenses/by/2.0), which permits unrestricted use, distribution, and reproduction in any medium, provided the original work is properly cited.
} 


\section{Introduction}

Time is a direct source of utility (Rajivan, 1999). The scarcity of time and the paucity of leisure time are at the centre of the discussion about the quality of contemporary life (Schor, 1991 quoted in Bittman and Wajcman, 1999). This appears to be particularly true for women. Women's activities have gradually shifted from the timeless world of their home to the timebound public sphere. However, workspace choices in formal settings outside their home are also gendered, as their work is mainly concentrated at home. The selection of work space of the women depends on the distance from their houses and opportunities to access the means of transport, jobs with less spatial mobility, etc. (Hanson and Pratt, 1995). As a result, they usually have limited choices in terms of employment opportunities than that of the men (Raju, 2011). Not only that, because of the fixed timings required in the public sphere, at a certain time their workload becomes double. Despite these constraints, women's engagement in the public sphere has increased over time. They have also encroached into the traditionally male space of administration, despite being aware of the negative aspects associated with it. For example, political factors like male dominated politics and political parties. Political party is considered as an organ of political structure. The party makes a crucial decision as to whether women should be allowed to contest for unreserved seats or not. It also determines the win ability of a candidate (Nair, 2012). For such reason, women have to share power to make place within the political parties through which Indian democratic system operates (Gupta, 2006). In administration, women also suffer due to the lack of protective security, coordination and networks with the members, leadership oriented training and supports from media. Evidently, women face subordinated behaviour and attitudes towards them (like ignorance, ridiculing, interrupting, threatening, discrimination in meeting and vote of no confidence for women) as they are elected in reserved seats (Palanthurai, 2012). In urban administration, women have the problems of decision making because of the barriers in personal and municipal levels. In personal level, they lack in experience of municipal functioning; social customs and taboos adversely affect their participation in the affairs of urban governance. At municipal level, attitudes and behaviours of male counterparts hinder the active participation of women as they are being suppressed morally as well as psychologically. Besides, the party wise political representation also obstructs the way of unity among the elected women on the women's causes (Rizvi, 2006). In India, the $73^{\text {rd }}$ and $74^{\text {th }}$ amendments to the Constitution in 1992 have given a new space of work for women in local governance. However, it is important to mention that education and reservation is not enough for women to join in governance and politics. Informally, they need a supportive family and a family that has political background, someone in the family who is willing to take over the care of the family and children (Srivastava, 2015).

The oppression of women's lives, which has been discussed in the previous section and their struggle against it, is not new. The movement albeit started much earlier, that is, during the second wave feminism (Peet, 2004). It started with the notion that personal is political. It validates personal experience as a basis for collective action and it allows people to place issues previously considered personal and private into the realm of political and public. After that, women who blamed themselves for their situations became optimistic and active and opened up debates and public discussion. During that period, Simone de Beauvoir's book, 'The Second Sex' (1949) had been translated into English in 1953. This book has explained how women's household work shifted from dominant economic activity in the primitive society (e.g. pottery making, weaving, gardening in their homes) to less important labour at present. Because with the advent of metals and agriculture, the economic work became larger in scale and due to its labour intensive nature, men became the service provider. As a result, women became subordinated within the 
private property of their homes. Such domestic subordination transformed into a social oppression as a consequence of economic oppression. Hence, women are required to take part in the production activities on large social scales though it is very difficult for them to reconcile their jobs while simultaneously managing the household activities (Borde et al., 2009).

Like in governance, as a local representative, women try to secure the demands of the citizens of their local area. They are like watchdogs, implementing the policies related to the needs of the common people with special reference to women (Paradza et al., 2010). In addition, women's increased participation in governance opens up more spaces for women. Besides, for the efficient and maximum utilisation of human resources, it is important that women are increasingly allowed in governance (Chowdhury, 1994 quoted in Panday, 2008). This is because they are capable of generating new ideas, approach to the governance and put the women's issues forward in public discussion. This in turn will unlock the potentials of many more women.

Scholars argue that women are the pathfinders of attacking social issues with different set of skills, leadership qualities and opinions (Joseph, 2011). I argue that it is the women who understands women's problems better. Men are guided more by political motives as they see it as a chance to enter state level politics; however, women are not (Upadhyay \& Bhardwaj, 2006). Women have also proved better team leaders than most men around them as they have deeper sense of loyalty and commitment. Such intangible and valuable resource can be best used by the women's participation in governance (Narain et al., 2006). In governance, women are believed to be more courageous about ensuring implementation of work related to development, especially on issues of women's development and empowerment (Kodoth et al., 2011). They are credited with good policy making, generation of self-employment opportunities, development of poorer areas, and development of facilities for basic services like drinking water, reducing gender gap and increasing the health care facilities especially for children (Beaman et al., 2006; Ghosh, 2003; Kulkarni, 2011; Ruet et al., 2005; Sathe, et al., 2013). In order to undertake these responsibilities, WCs are required to spend a certain amount of time in the municipality and in their concerned wards. However, as women, they also have to allocate a certain fixed amount of time daily for their routine household chores and their own maintenance, especially in the case of married women. The household chores are divided into householdrelated work and activities performed within the home, and household-related work and activities performed outside. There are two types of household activities, which are performed outside the home. These are regular and occasional works. Regular household works performed outside the home includes buying groceries, dropping children to school and coaching classes, and to cultural activities. Occasional household works performed outside the home includes shopping for household items including clothes for children, visiting the doctor for medical treatment of family members, collecting groceries from ration shops, carrying out banking transactions, and paying telephone and electricity bills. Thus, household duties have actually expanded and diversified. A woman has to allocate her time between these three competing types of works-work of a local representative, household works and time for their own leisure. For these reasons, the present research focuses on the changing nature of time use patterns of women with their political participation in urban governance in the cities of West Bengal. Women's participation in local governance will lead to additional investment of time for the work of local representative in their daily routine. This is turn would change their social life. The additional investment of time for the work of the local councillor is also related to the matter of honorarium paid to them, which is also a focus of this research.

In local governance, women have to undertake all the work similar to the amount of work 
taken by a man representative. However, in the house, gender attitudes, gender roles and others' expectations result in uneven distribution of work between men and women (Lahiri-Dutt and Sil, 2014). Not only that, norms of behaviour and masculinity prevent men to do housework, that is, more a husband depends on wife less he works at home (Bittman et al., 1999). As a result, women engaged in earning for the household or those who have an engagement in the public sphere, tend to do more housework when compared to that of a man (Lahiri-Dutt and Sil, 2014). For these reasons, the lack of time to manage both household affairs and the responsibilities of a councillor are major challenges for a majority of women in urban governance. Often they feel guilty about remaining out of their homes for long hours. This is a psychological problem faced by most of the women councillors (henceforth, WCs) (Ghosh et al., 2005). To analyse such problems related to time use of elected women in urban governance, empirical research has been conducted in four selected small cities located in four different geographical divisions of West Bengal. These are Darjeeling in the northern hills; Balurghat, in the northern plain; Raniganj, located in the western plateau, and Chinsurah, located in the eastern plain of Bengal. This research probes the following issues:

- The hours of work of the women as local councillors;

- The time they spend in their homes to perform household works and its influence on their works as a local councillor;

- The exact time of their leisure and how they spend it, considering the influences on household works as well as the works of a councillor; and

- Their perception about the honorarium they receive for the works as a councillor and whether it is justified or not.

\section{Methodology}

The methods used in the present research include both quantitative and qualitative. The quantitative method includes the tool, that is, the time-use diary. The time-use diary is used to enable respondents to report all activities undertaken over a prescribed period of time and the time when each activity begins and ends. To collect the required data, a 24-hour diary is used, which was sub-divided into two basic types-a full-time diary and a light time diary. The full-time diary is again of two types: open time interval and fixed time interval. In this study, the open time interval full-time diary was used to retrieve information on how the WCs spend their time throughout the course of a day. In this diary, the respondents reported what activity they were doing when they began the day; what activity came next and at what time this activity began and ended, and so on, successively through the 24 hours of the day. The interval of time within which an activity is reported is not fixed. Such recording of the duration of each activity is called an episode (Atlantic, n.d.; Budlender, 2007; Pandey, 2000; Hirway, 1999; Time Use Surveys, 2013). Time is measured in hours and minutes per day, out of a total of seven days in one week (weekly average), which was our reference period for collecting the data. Recording of activities is targeted for a normal day, not for a weekly variant or abnormal day. The weekly variant day allows for a general day off and the abnormal day is a day in which all usual functions of the household may be altered for a special reason, such as due to the arrival of an unexpected guest, illness or even a local festival (Rajivan, 1999). This is because we have tried to record time-use statistics of the respondents' economic as well as household activities.

In the present context, the 1995 classification of activities recommended by the United Nation Development Programme (UNDP) has been followed. The trial international classification for time-use activities differentiates activities on the basis of whether an activity is within the System of National Accounts (SNA) production boundary or within 
the general production boundary outside the SNA boundary, or non-productive. In total, 154 activities have been grouped into a 9-fold classification, and these 9 groups of major activities have been further classified into 3 broad divisions by the United Nations: (A) SNA activities [(I) primary, (II) secondary and (III) tertiary activities which are paid works]; (B) the extended-SNA activities [(IV) household maintenance, management and shopping for own household, (V) care for children, the sick, elderly and disabled for own household and (VI) community services and help to other households]; and (C) non-SNA activities [(VII) learning, (VIII) social and cultural activities, mass media and (IX) personal care and selfmaintenance] (Lahiri-Dutt and Sil, 2014; UNDP, 1995).

The sampling technique used is mainly the purposive type, which depends on the conditions and purposes of dealing with different issues. The snowball sampling technique has been used for the qualitative survey. The quota for women's participation in municipal governance is only 33 per cent of the total number of elected councillors (according to the $74^{\text {th }}$ constitutional amendment). However, in some Urban Local Bodies (ULBs), they are also elected into the unreserved seats. As a result, the number of WCs is not large. For this reason, the total elected WCs (the universe) from each small city have been taken as a sample. However, the non-response from a few WCs even after repeated communications remains as an obstacle that did not allow us to cover the total figure of the WCs. However, the number of non-responses is very less (about eight women councillors from the cities).

\section{Study Area}

The area under the study covers four selected cities of West Bengal-Raniganj, Balurghat, Hooghly-Chinsurah and Darjeeling. The primary basis for the selection of study areas is the physiographic divisions (based on topography) of West Bengal. The northern part of West Bengal is covered with hills, middle portion is composed of northern plains and the southern part has both plateau and plain regions.
The secondary basis for the selection of study areas are - small cities with a population of less than $200,000 \mathrm{~s}$ and the percentage of WCs on the municipal boards of the cities. It should be noted here that the municipal boards, which were developed in the election year of 2008 to 2011 have been selected. For this purpose, a statistical table was developed, containing small cities with their present population, municipal board (2008-11), percentage of representation of the elected women councillors (Table 1 ). On the basis of these criteria, all the four small cities were selected to represent the picture of West Bengal as a whole. Among the four cities, three are headquarters of the districts. Headquarter of Darjeeling district is Darjeeling city, headquarter of Dakshin Dinajpur is Balurghat, while Hooghly-Chinsurah is the headquarter of Hooghly district. Raniganj in Burdwan district has been selected because of its location in the plateau region (Figure 1).

As noted above, amongst the small cities, Raniganj is in the plateau region and is located in the western part of Burdwan district $\left(23^{\circ} 62^{\prime} \mathrm{N}\right.$ and $\left.87^{\circ} 13^{\prime} \mathrm{E}\right)$ with an area of 24.09 sq. $\mathrm{km}$. The municipal board is governed by the Communist Party of India (Marxist) [CPI (M)]. The population is about, $1,29,804$ in 2011. It has 22 wards, of which 10 wards have WCs.

In the Eastern part, Hooghly-Chinsurah is a part of Rurh Bengal of the southern plain. It is located in the Hooghly district $\left(22^{\circ} 90^{\prime} \mathrm{N}\right.$ and $88^{\circ} 39^{\prime} \mathrm{E}$ ) with an area of 17.27 sq. $\mathrm{km}$. Its municipal board is led by the All India Trinamool Congress (AITC). The population of the city is about $1,80,502$ in 2011. It has 30 wards, of which 11 wards have WCs.

From the middle plain of West Bengal, Balurghat $\left(25^{\circ} 22^{\prime} \mathrm{N}\right.$ and $\left.88^{\circ} 76^{\prime} \mathrm{E}\right)$ is situated in the barind land (land of old sediment). It has a population of $1,51,299$. There is a woman chairperson in the municipal board of the city. Revolutionary Socialist Party (RSP) is in power of the municipal board (2008). It has 23 wards, with an area of 10.76 sq. km. Among the 23 wards, 8 wards have elected WCs. 
In the extreme north, Darjeeling $\left(27^{\circ} 03^{\prime} \mathrm{N}\right.$ and in power. The district has 32 wards, with an $88^{\circ} 16^{\prime} \mathrm{E}$ ) is located at the hill region of West area of $10.57 \mathrm{sq} . \mathrm{km}$. Among the 32 wards, 15 Bengal. It has a population of $1,18,805$. From are headed by WCs.

2011, the Gorkha Janamukti Morcha has been

\begin{tabular}{|c|c|c|c|c|}
\hline District & Cities & $\begin{array}{c}\text { Total Population } \\
\text { (2011) }\end{array}$ & $\begin{array}{c}\text { Political nature of } \\
\text { Municipal Board } \\
(2008-11)\end{array}$ & $\begin{array}{c}\text { Representation of } \\
\text { Women } \\
\text { Councillors } \\
\text { (in Percentage) }\end{array}$ \\
\hline \multirow[t]{8}{*}{ Burdwan } & Daihat & 24397 & INC & 35.71 \\
\hline & Jamuria & 145276 & CPIM & 34.78 \\
\hline & Kalna & 56722 & AITC & 33.33 \\
\hline & Katwa & 81615 & INC & 52.63 \\
\hline & Memari & 41451 & AITC & 37.5 \\
\hline & Raniganj & 129441 & CPIM & 45.45 \\
\hline & Burdwan & 314265 & CPIM & 37.14 \\
\hline & Guskara & 35388 & CPIM & 43.75 \\
\hline \multirow[t]{11}{*}{ Hooghly } & Arambag & 66175 & CPIM & 33.33 \\
\hline & Baidyabati & 121110 & AITC & 36.36 \\
\hline & Bansberia & 103920 & AITC & 45.45 \\
\hline & Bhadreswar & 101477 & AITC & 36.36 \\
\hline & Champadany & 111251 & AITC & 36.36 \\
\hline & $\begin{array}{l}\text { Hooghly- } \\
\text { Chinsurah }\end{array}$ & 177259 & AITC & 36.66 \\
\hline & Konnagar & 76172 & AITC & 45 \\
\hline & Rishra & 124577 & AITC & 39.13 \\
\hline & Serampur & 181842 & AITC & 37.93 \\
\hline & Tarakeswar & 30947 & AITC & 33.33 \\
\hline & Uttarpara & 159147 & AITC & 50 \\
\hline \multirow[t]{4}{*}{ Darjeeling } & Darjeeling & 118805 & GJM & 46.87 \\
\hline & Kalimpong & 49403 & GJM & 47.83 \\
\hline & Kurseong & 42446 & GJM & 35 \\
\hline & Mirik & 11513 & GJM & 33.33 \\
\hline \multirow[t]{2}{*}{ DakshinDinajpur } & Balurghat & 151416 & RSP & 34.78 \\
\hline & Gangarampur & 56217 & INC & \\
\hline
\end{tabular}




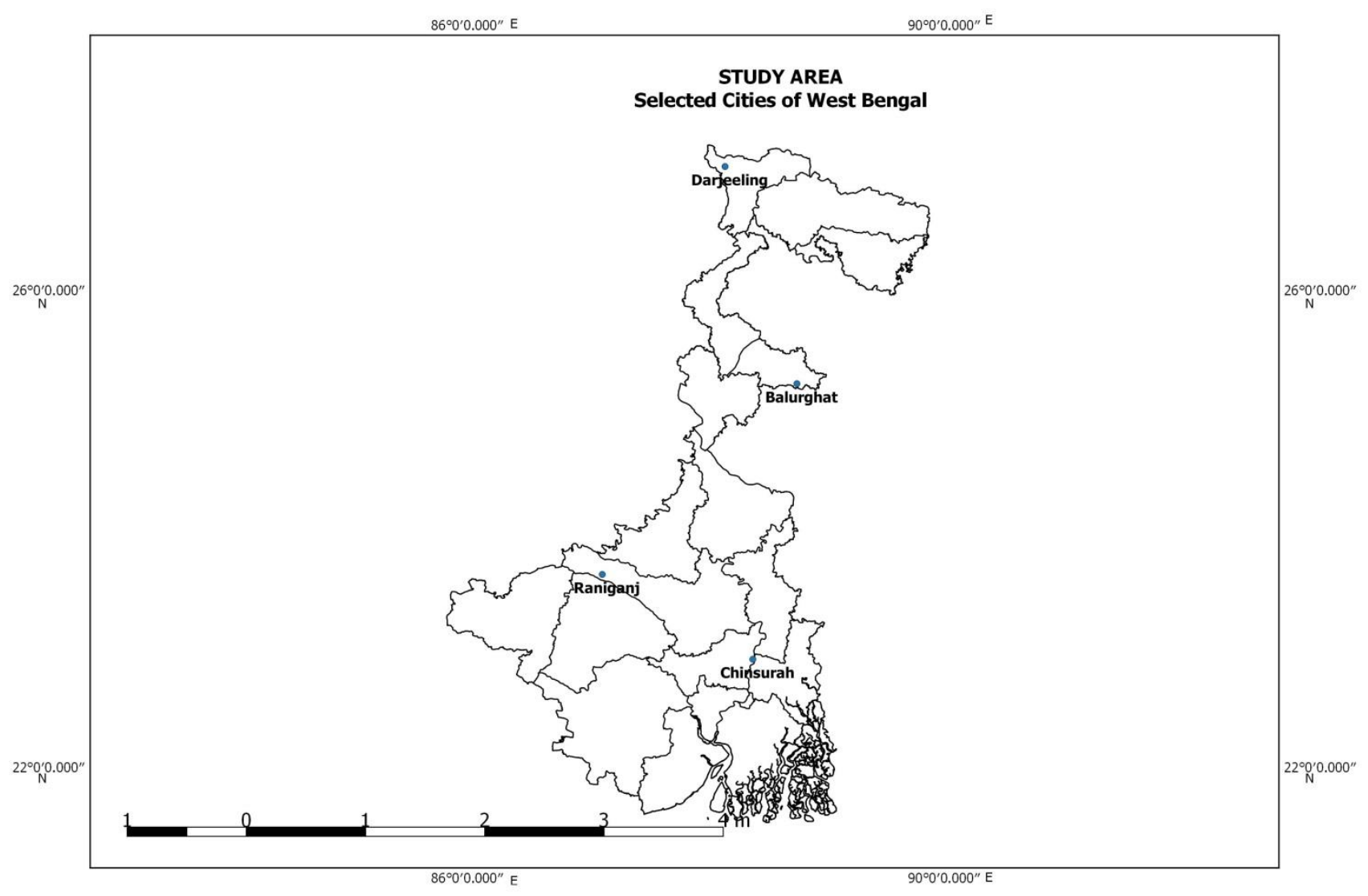

Figure 1: Selected Cities of West Bengal (Source: Authors)

\section{Brief Profile of the Women Councillors}

To record the time-use activity, we have classified the surveyed WCs in the four cities according to their employment and marital status. It was found that there are few employed WCs who are engaged in other economic activities. In terms of marital status, the data shows that the WCs are married, unmarried or widowed (Table 2).

Darjeeling Municipality has 32 elected councillors, one from each ward. Among them, 15 are WCs. Six have been undertaking higher responsibilities, as they held the positions of Chairperson -in-Council (CIC). The age group of the interviewed councillors ranges in between 30 to 60 years (three are of more than 50 years of age). Most of them are married. However, there are one unmarried and one widowed among them. In terms of religious affiliation, ten are Hindus, and four are from the Buddhist community.
Balurghat municipality has 23 councillors, of which eight are women, including the chairperson. Except for the chairperson, there are no WCs undertaking the role of the municipality's Chairperson -in-Council (CIC). The ages of the seven surveyed WCs vary from 29 to more than 60 years. If the division of the age groups are made, it is found that two are below 40 years, one in between 40 to 50 years, two within 50 to 60 years and another, two above 60 years. There is an interesting fact behind the selection of women candidates nominated as a councillor-except for three, all the other are either widowed or unmarried. It is also important to mention that the currently married WCs were unmarried when they were elected.

Raniganj has a total of 22 wards. Among these, 10 wards have elected WCs. Among the eight interviewed WCs, there is only one CIC (Chairperson -in-Council) councillor holding the Department of Health, Childcare and MGNREGS (Mahatma Gandhi National Rural Employment 
Guarantee Scheme) cells. All others are general councillors. There is one WC from the opposition party (name the party here. In terms of religion, most of them are Hindus. However, two are Muslims. There is one widowed and seven married WCs.

In Chinsurah, among the 30 wards, 11 wards have WCs. However, it should also be noted that there are 10 reserved seats, and only one woman has been elected in the general seat.
Among the 11, nine were interviewed. Their ages vary in between 38 to 57 years. Of these, there are three below 40 years of age, four within the age range of 40 to 50 years, and two above 50 years of age. All of them are married and most of them have lived in Chinsurah from their birth, securing the identity of a daughter as well as a daughter-in-law in the same city and in some cases, in the same ward.

\begin{tabular}{|c|c|c|c|c|c|c|c|c|}
\hline \multirow[t]{2}{*}{ Cities } & \multirow[t]{2}{*}{$\begin{array}{l}\text { No of Total } \\
\text { Councillors }\end{array}$} & \multirow[t]{2}{*}{$\begin{array}{c}\text { Total Women } \\
\text { Councillors }\end{array}$} & \multirow{2}{*}{$\begin{array}{c}\text { Surveyed } \\
\text { Women } \\
\text { Councillors }\end{array}$} & \multicolumn{3}{|c|}{ Marital Status } & \multicolumn{2}{|c|}{$\begin{array}{l}\text { Occupational } \\
\text { Status }\end{array}$} \\
\hline & & & & Married & $\begin{array}{c}\text { Un- } \\
\text { married }\end{array}$ & Widow & Employed & $\begin{array}{c}\text { Un- } \\
\text { employed }\end{array}$ \\
\hline Darjeeling & 32 & 15 & 14 & 12 & 01 & 01 & 04 & 10 \\
\hline Balurghat & 23 & 08 & 07 & 3 & 2 & 2 & 03 & 04 \\
\hline Raniganj & 22 & 10 & 08 & 07 & - & 01 & - & 08 \\
\hline Chinsurah & 30 & 11 & 09 & 09 & - & - & - & 09 \\
\hline
\end{tabular}

Source: Field Survey, 2013-2015

\section{Time-use of the Women Councillors}

A detailed time-use survey of the WCs in the four cities of West Bengal provides a comparative picture of their contribution on three types of time-use activities (that is, SNA, extended-SNA and non-SNA). In this context, the SNA, extended-SNA and non-SNA activities (previously discussed in details) have been analysed on the basis of their employment status that is, employed(who are engaged in paid employment besides their work of local councillor) and unemployed $\}$ and marital status (married, unmarried and widowed). Here, the total time invested by the WCs in the work of the local representative and in other economic activities (paid employment) is considered as the time for doing SNA activities of the women councillors.

Now we compare the contribution of WCs regarding the weekly average time spent on SNA, extended-SNA and non-SNA activities on the basis of their employment as well as their marital status.
Table 3 clearly depicts the greater workload of household duties of the unemployed WCS in the selected cities of West Bengal. However, in literature it is found that unemployed WCs can spend more time in the work of the local councillor, as they have no extra burden of paid employment like the one the men have (Ghosh et al., 2005 quoted in Ghosh, 2009). This finding remains contrary to the findings as reported in previous literature. Now if we analyse the time use activities of the unemployed WCs on the basis of their marital status, it is quite obvious that the married unemployed WCs spend more time in extended-SNA activities (average 66 to 84 hours in a week) than that of the widowed and unmarried unemployed WCs. As stated in literature, unpaid care and household chores are significant functions to maintain the standard of living and well-being of the family in a society (Keall et al., 2007). However, such work may limit or prevent people from participating in paid work. This in turns affects their incomes and access to goods and services. However, in Darjeeling, married unemployed 
WCs spend less time in extended-SNA activities (as there is no gender division of work between men and women) than that of the married unemployed WCs of the other cities of West Bengal.

As a result, except for the married unemployed WCs of Darjeeling, all of them get less time to spend in SNA activities (on average, 33 to 43 hours in a week) due to their involvement in extended-SNA activities. However, in Balurghat, discipline of the woman chairperson in the municipality keeps the WCs' active in their SNA activities (work of the local councillor) despite of their household duties. For this, , the married, unmarried and widowed unemployed WCs spend more or less same time for their SNA activities (on average 36 to 44 hours in a week). Whereas, in Chinsurah, married unemployed WCs spend less time in SNA activities (on average 33 hours in a week). They only attend the municipality office and the other works of the local councillor are done by their associated men members (husband or party members). They are elected in the proxy seats ${ }^{1}$ because of reservation of seats for women. As a result, in terms of work and decision making activities, they remain as proxy women. ${ }^{2}$ This might have same implications, as Hossain (2012) observed that the women have nothing to do actually for the well-being of the community, as their work is done by their husbands. From Table 4, it is clearer that, unemployed WCs of Chinsurah spend less time in municipality and ward visits (on average, 3 to 6 hours in a week). The reason is already stated earlier.

The unemployed WCs of Balurghat and Darjeeling spend more time in the work of the local councillor outside their home (that is, for ward visit and municipality work). Among them,

\footnotetext{
${ }^{1}$ The seat in which a woman is elected because of reservation of seats for women to secure the seat for the men member of next generation (Panday, 2008; Palanthurai, 2012; Kulkarni, 2011; Ghosh et al, 2005).

${ }^{2}$ Woman who is not empowered to take her decisions independently. She is always influenced by the men members (husband or concerned political party members) (Nair, 2012; Singh, 2006).
}

unmarried and widowed contributes more time in the work outside their homes (Table 4) because of less burdens in household chores. In Darjeeling, unemployed WCs prefer to stay in the municipality (on average, 22 to 35 hours in a week) to get to know the problems of the common people and to get the essential information regarding the development of their ward. Here, the ward visit is quite hard for the WCs because of hilly terrain and uneven distribution of wards along the different spurs of the hill. In Raniganj, five out of eight WCs undertake ward visits for three to seven hours in a day, while the others prefer to wait in the local party office of their ward to meet the common people (about 16 to 28 hours in a week).

In case of the time of non-SNA activities, unemployed married WCs of Darjeeling spend more time (on average 56 hours in a week) than that of the other cities of West Bengal (Table 3). The reason is already stated earlier. Moreover, in case of unmarried WCs in all cities, a reduction in time spent on extendedSNA activities results in a corresponding or greater increase in time spent on non-SNA activities (on average 57 to 63 hours in week).

\section{Comparison between Unemployed and Employed Women Councillors in terms of Time-use Activities}

In Darjeeling, married employed WCs spend less time (on average 59.5 hours in week) in extended-SNA activities than that of the unemployed married women councillors (on average 66.69 hours in a week) (Table 3 and Table 5). The reason is that the employed WCs needs to share their time in-between other economic activities and works of the local councillor. As a result, they get less chance to spend their time in extended-SNA activities. Most of WCs are employed as teachers in English medium model schools (morning section). However, they spend less time (on average 17.5 hours in a week) for other economic activities than the time they spend in municipality office (on average 26.25 hours in week) (Table 6). The reason is that their working hours start very early in the morning, 
at about 5 am and end at $3.30 \mathrm{pm}$. They cannot work up to $5 \mathrm{pm}$ or more because of cold climatic conditions. As a result, in Darjeeling, hours for the work of local councillor start from
12 noon to $3 \mathrm{pm}$ and there is no overlapping in sharing the time between other economic activities and the work of the local councillor.

\section{hours for the work of local councillor start from}

\section{Table 3: Time-use of Unemployed Women Councillors}

Cities

Time-use of Unemployed Women Councillors with Different Marital Status

\section{Weekly Average Time in hours}

\begin{tabular}{ccccc}
\hline Marital Status & Hours of SNA & Hours of Extended-SNA & Hours of Non-SNA & Total \\
& Activities & Activities & Activities & hours
\end{tabular}

\begin{tabular}{|c|c|c|c|c|c|}
\hline \multirow[t]{3}{*}{ Darjeeling } & Married & 45.18 & 66.69 & 56.13 & 168 \\
\hline & Unmarried & 36.92 & 74 & 57 & 167.92 \\
\hline & Widow & 49 & 70 & 49 & 168 \\
\hline \multirow[t]{3}{*}{ Balurghat } & Married & 43.75 & 71.75 & 52.5 & 168 \\
\hline & Unmarried & 42 & 63 & 63 & 168 \\
\hline & Widow & 36.19 & 82.83 & 49 & 168.02 \\
\hline \multirow[t]{2}{*}{ Raniganj } & Married & 42.5 & 75.14 & 50.29 & 167.93 \\
\hline & Widow & 59.5 & 52.5 & 56 & 168 \\
\hline Chinsurah & Married & 33.22 & 83.67 & 51.11 & 168 \\
\hline
\end{tabular}

Source: Field Survey, 2013-2015; computed by author.

Note: The figure of total time for each may not be exactly equal to168 due to rounding off effect.

In Balurghat, most of the employed WCs are also teachers. Tables 7 and 8 depicts the picture that the unmarried WCs in Balurghat spend more time in SNA activities (on average 98 hours in a week) mostly in municipality works (on average 49 hours in a week). They spend less time in household chores as they have fewer burdens of household duties when compared to that of the married unemployed WCs.
Table 7 also illustrates the fact that the widowed employed WCs of Balurghat spend more time in non-SNA activities as the burden of household duties are completed by their daughter(s)-in-law and sons. They spend their leisure with their grandsons and granddaughters. In Darjeeling, employed WCs spend more time in non-SNA activities (on average 57.75 hours in a week).

\section{Table 4: System of National Accounts (SNA) Activities of Unemployed Women Councillors}

Cities

Distribution of SNA activities of Unemployed Women Councillors of

Different Marital Status

Marital Status

Weekly Average Time in Hours

\begin{tabular}{cccc}
\hline \multicolumn{4}{c}{ Weekly Average Time in Hours } \\
\hline $\begin{array}{c}\text { Hours spent in } \\
\text { Municipality }\end{array}$ & $\begin{array}{c}\text { Hours spent } \\
\text { in ward visit }\end{array}$ & $\begin{array}{c}\text { Hours to meet the } \\
\text { local people at house } \\
\text { or at party office }\end{array}$ & $\begin{array}{c}\text { Total hours of } \\
\text { SNA activities }\end{array}$ \\
\hline
\end{tabular}

\begin{tabular}{|c|c|c|c|c|c|}
\hline \multirow[t]{3}{*}{ Darjeeling } & Married & 30 & 15.18 & & 45.18 \\
\hline & Unmarried & 22.92 & 14 & & 66.92 \\
\hline & Widow & 35 & 14 & & 49 \\
\hline \multirow[t]{3}{*}{ Balurghat } & Married & 33.25 & 10.5 & & 43.75 \\
\hline & Unmarried & 31.5 & 10.5 & & 42 \\
\hline & Widow & 29.19 & 7 & & 36.19 \\
\hline \multirow[t]{2}{*}{ Raniganj } & Married & 12.78 & 13.71 & 16 & 42.49 \\
\hline & Widow & 31.5 & & 28 & 59.5 \\
\hline Chinsurah & Married & 5.99 & 3.5 & 23.72 & 33.21 \\
\hline
\end{tabular}

Source: Field Survey, 2013-2015; computed by author 


\section{Table 5: Time-use of Employed Women Councillors of Darjeeling}

Time-Use Survey of Employed Women Councillors

$$
\text { Weekly Average Time in Hours }
$$

\begin{tabular}{ccccc}
\hline Cities & Hours of SNA Activities & $\begin{array}{c}\text { Hours of Extended-SNA } \\
\text { Activities }\end{array}$ & $\begin{array}{c}\text { Hours of Non-SNA } \\
\text { Activities }\end{array}$ & Total hours \\
\hline Darjeeling & 57.75 & 59.5 & 50.75 & 168
\end{tabular}

\section{Source: Field Survey, 2013-2015}

\section{Table 6: System of National Accounts (SNA)Activities of Employed Women Councillors of} Darjeeling

Distribution of SNA Activities of Employed Women Councillors

Weekly Average Time in Hours

\begin{tabular}{ccccc}
\hline Cities & $\begin{array}{c}\text { Hours spend in } \\
\text { Municipality }\end{array}$ & $\begin{array}{c}\text { Hours Spend in } \\
\text { ward visit }\end{array}$ & $\begin{array}{c}\text { Hours of other } \\
\text { economic activities }\end{array}$ & $\begin{array}{c}\text { Total hours of SNA } \\
\text { activities }\end{array}$ \\
\hline Darjeeling & 26.25 & 14 & 17.5 & 57.75 \\
Source: Field Survey, 2013-2015; computed by author & & \\
\hline
\end{tabular}

\section{Table 7: Time-use of Employed Women Councillors of Balurghat}

Time-use of Employed Women Councillors

Cities Weekly Average Time in hours

\begin{tabular}{cccccc}
\hline & Marital Status & Hours of SNA Activities & $\begin{array}{c}\text { Hours of } \\
\text { Extended-SNA } \\
\text { Activities }\end{array}$ & $\begin{array}{c}\text { Hours of } \\
\text { Non-SNA } \\
\text { Activities }\end{array}$ & $\begin{array}{c}\text { Total } \\
\text { hours }\end{array}$ \\
\hline Balurghat & Married & 70 & 42 & 56 & 168 \\
\hline & Unmarried & 98 & 14 & 56 & 168 \\
\hline & Widow & 73.5 & 31.5 & 63 & 168 \\
\hline
\end{tabular}

Source: Field Survey, 2013-2015; computed by author

\section{Table 8: System of National Accounts (SNA) Activities of the Employed Women Councillors of Balurghat}

\begin{tabular}{cccccc}
\hline \multicolumn{4}{c}{ Distribution of SNA activities of Employed Women Councillors } \\
\hline Marital Status & Hours spend in \\
Municipality & $\begin{array}{c}\text { Hours } \\
\text { Spend in } \\
\text { ward visit }\end{array}$ & $\begin{array}{c}\text { Hours to meet } \\
\text { the local people } \\
\text { at house or at } \\
\text { party office }\end{array}$ & $\begin{array}{c}\text { Hours of Other } \\
\text { Economic } \\
\text { Activities }\end{array}$ & $\begin{array}{c}\text { Total hours of } \\
\text { SNA activities }\end{array}$
\end{tabular}

\begin{tabular}{ccccccc}
\hline Balurghat & Married & 28 & 14 & 28 & 70 \\
\cline { 2 - 7 } & Unmarried & 49 & 21 & 28 & 98 \\
\cline { 2 - 7 } & Widow & 31.5 & 14 & 28 & 73.5
\end{tabular}

Source: Field Survey, 2013-2015; computed by author

Time-use Activities and its Relation with worth of work is judged from the payment Honorarium of the Women Councillors made for it. The distribution of time for paid

In today's world, the importance of anything is measured in terms of money; the time and and unpaid works are highly gendered in terms of men and women. The domestic work is 
undervalued and unprotected (Harpreet et al., 2014). There is no availability of state-level data regarding the time spent by women on domestic activities (Pandey, 2000). Now in the present context, we will analyse the value of their time for the work of local councillor as it is related to spending of time to provide services to the common people. In the previous section, we have analysed the distribution of average time of the WCs for the different types of works. Using this analysis, we have found that in the cities, among the unemployed WCs, married councillors have spent on average 31 hours, while unmarried and widowed councillors spent 39 hours in a week for the works of the local councillors (that is, municipality work and ward visit). In addition, employed married WCs in the cities spent on average 41 hours in a week for the work of the local councillor. Unmarried employed WCs of Balurghat spent about 70 hours in a week for the work of the local councillor. Now, in the present section, we will analyse the status of their honorarium in relation to the time spent for it.

In Darjeeling, the honorarium of the WCs ranges from ₹1575 to 2200 per month. It is also dependent on their position whether they are in CIC (Chairperson-in-council) or not. Not only that, portion of this given money is usually earmarked to donate to the club during festivals and it is very low in comparison to the recent surge in prices of everyday commodities. For such reasons, one-woman councillor has said:

Low honorarium is an indirect encouragement for doing corruption.

This fact is proven among the local councillors of Mumbai, Chennai, Delhi and Kolkata, where the corruption is high because of low honorarium. Hence, there is a need to rethink about the spending of government money. For example, government spends ₹80,000 per month for a single MLA to cover costs of hiring a personal assistant, upkeep of a car, cell phone and so on. Such facilities should be extended to the councillors because they do maximum works (Ghosh et al., 2005).
In Balurghat, the honorarium is ₹1500 per month. Except for the WCs who are schoolteachers, the honorarium is also problematic in terms of present expenditure for the other WCs. It is quite clear that the perception about the honorarium amongst the WCs depends on their status of income as well as expenditure. WCs from the low-income group family raise their voice to increase the amount of honorarium. Following this, it was raised from ₹700 to ₹1000 per month. It is also nominal in respect of expenses incurred for mobile phones and transport. The functions of a councillor result in expenses on telephones, transport and tea, which is not covered by his or her monthly, allowances (Ghosh et al., 2005). In Chinsurah, WCs receive an honorarium of ₹1500, with an additional ₹200 for mobile recharge. It is very low for them as they are homemakers and depend on their husband's income. One-woman councillor said:

We are in the lower position than the municipality labours in terms of salary. We have no respect in the municipality.

An argument focusing on the official status of the councillors underlines that local politics is a part-time, voluntary activity as proven by the nominal nature of councillors' allowances (Ghosh et al., 2005).

From the previous discussion in this section, it is clear that the honorarium is not same in all the cities in West Bengal and the expected amount of salary for their work is essential for them. They work for the people in addition to trying to fulfil various needs of their ward. Their continuous engagement with the work also deserves a proper salary to allow them to undertake their work wisely; otherwise, they will lose interest in the long run.

\section{Conclusion}

From the present study, it is evident that the time-use pattern of the WCs in the cities differs according to geographical regions. For example, unemployed WCs with different marital status spend more time in extended-SNA activities, which are mostly related to their household 
works. Among the SNA activities, they spend more of their time at the municipality office or at the local party office than in ward visits. Employed WCs spend more time in SNA activities as they have to undertake the work of a councillor as well as other economic activities. The gap between the hours spent by the WCs on SNA, extended-SNA and non-SNA activities is very low in the case of Darjeeling. However, the gap is very high in case of Balurghat, as they spend more time in the municipality office irrespective of their other economic activities. Another reason is that the time spent on the other economic work by the WCs does not coincide with the time they spend in the municipality. In Darjeeling, married, unemployed WCs spend less time in extendedSNA activities than the unmarried and widowed WCs. However, in other cities, they spend more time in extended-SNA activities.

The time use pattern of the local councillors' works shift from municipality works and ward visits to work from home in the north and south of West Bengal. It is found that WCs of northern and middle Bengal are less bound to their household activities than those of south Bengal. As a result, WCs of South Bengal spend relatively less time in the municipality as well as in ward visits. This is also a cause of their proxy representation in urban governance. Such proxy representation is further encouraged by the limited economic opportunities in this field. Therefore, though household work is considered as extended-SNA activity, it remains unpaid in a developing country like India for emotional reasons. These household works often hinders the path of the women to work in the field of local governance. For instance, most political parties are hesitant to include women in their core group, as they are required to fulfil their household obligations as well (Haug, 2012; Panday, 2008).

The work of the councillors is also a timeconsuming job as it is related to service delivery and problem solving. However, it is wrapped in the cover of social service, and therefore remains underpaid. The honorarium is very low, at only ₹1500-2200 per month, and it also depends on their position, whether they are general councillors or chairperson -in-council (CNC). Such lack of economic freedom and the enormous stress on the use of time is a major cause of discouragement for women to enter in this field. Such initial discouragement does not offer a bright vision of the future, despite the reservation for women in urban governance.

\section{References}

Beaman, L., Duflo, E., Pande, R., \&Topalova, P. (2007).Women Politicians, Gender Bias, and Policy-making in Rural India.Unicef; Background Paper, 03-23. Retrieved June 20, 2013.

Bittman, M., \&Wajcman, J. (1999). The Rush Hour: The Quality of Leisure Time and Gender Equality. SPRC Discussion Paper No. 97, 01-22. Retrieved December 29, 2014.

Borde, C., \& Malovany-Chevallier, S. (Trans.). (2009). The Second Sex; Simone De Beauvoir. Retrieved January 5, 2017, from www.vintagebooks.com

Budlender, D. (2007). A Critical Review of Selected Time Use Surveys (pp. 01-44, Gender and Development Programme Paper No. 2).United Nations Research Institute for Social Development. Retrieved December 29, 2014.

Ghosh, A. (2003). 'Women's Reservation and Electoral Politics in Urban Local Bodies: An Analysis of Chennai Municipal Corporation Elections. Indian Journal of Gender Studies, 119-140. doi:10.1177/097152150301000106

Ghosh, A., \& Lama-Rewal, S. T. (2005).Democratization in Progress Women and Local Politics in Urban India. New Delhi: Tulika Books.

Ghosh, J. (2009). Transcending gender Reservation, representation and identity among elected women representatives in municipal politics (Published Master of Science dissertation). University of Oxford. Retrieved March \& April 2013.

Gupta, S. (2006).Political Empowerment of Women in Urban Local Bodies and the 74th constitution Amendment: Dispelling Doubts and Devising Future Strategies. In Empowerment of Women in Urban 
Administration (Experiences and Strategies) (pp. 67-80). New Delhi: Serials Publications.

Hanson, S., \& Pratt, G. (1995).Gender, Work and Space. London: Routledge.

Harpreet, D., \& Anupama, U. (2014).The Timeuse Survey of Rural Punjab: Measuring the Unmeasured. Rotterdam, Netherlands: IARIW 33rd General Conference. Retrieved December 29, 2014.

Haug, M. (2012). Women's Political Participation at the Sub-national Level in Nepal (UN WOMEN South Asia Country Review Series on Women's Political Leadership, pp. 05-20, Publication).Norway: Norwegian Institute for Urban and Regional Research, UN Women. Retrieved April 30, 2013.

Hiraway, I. (1999). Time Use Studies: Conceptual and Methodological Issues with Reference to the Indian Time Use Survey (pp. 01-18). Ahmedabad: International Seminar on Time -use Studies. Retrieved December 17, 2014.

Hossain, M. A. (2012). Influences of Social Norms and Values of Rural Bangladesh on Women's Participation. Indian Journal of Gender Studies, 19(3), 393-412. doi:10.1177/097152151201900303.

Joseph, V. (2011).Capability of Elected Women Representatives on Gender Issues in Grassroots Governance. New Delhi: Concept Publishing Company Pvt. Ltd.

Keall, M., Baker, M., \& Montgomery, H. (2007).Time Use Survey Scoping Paper. Statistics New Zealand, 01-25. Retrieved December 30, 2014.

Kodoth, P., \& Mishra, U. S. (n.d.).Gender Equality in Local Governance in Kerala. Economic and Political Weekly, XLVI(38), 36-43. Retrieved July 02, 2012, from www.epw.in.

Kulkarni, S. (2011).Women and Decentralised Water Governance: Issues, Challenges and the Way Forward. Economic and Political Weekly, XLVI(18), 64-72. Retrieved Aug. \&sept., 2012, from www.epw.in.
Lahiri-Dutt, K., \& Sil, P. (2014). Women's 'double day' in middle-class homes in Small Town India. Contemporary South Asia; Routledge, 02-15. doi:10.1080/09584935.2014.979762.

Nair, J. (2012). All in the Family? Gender, Caste and Politics in an Indian Metropolis. In Mapping The Field Gender Relations in Contemporary India (Vol. 2, pp. 464-497). Kolkata, West Bengal: Mandira Sen for STREE.

Narain, K., \& Mridubhashini, M. (2006).Dynamics of Empowering Women in Urban Development. In Empowerment of Women in Urban Administration (Experiences and Strategies) (pp. 184-193). New Delhi: Serials Publications.

Palanthurai, G. (2012). Elected Women Representatives and Empowerment. New Delhi: Concept Publishing Company Pvt. Ltd.

Panday, P. K. (2008).Representation without Participation: Quotas for Women in Bangladesh. International Political Science Review, 29(4), 489-512. Retrieved June 19, 2013, from www.jstor.org.

Pandey, R. N. (2000). Sampling Issues in Time Use Survey- Indian Experience (pp. 02-08, Working paper). New York: Country Paper for the Expert Group Meeting on Time Use Survey. Retrieved June 19, 2013.

Paradza, G., Mokwena, L. G., \& Richards, R. (2010).Assessing the Role of Councillors in Service Delivery at Local Government Level in South Africa (pp. 6-90, Rep. No. 125). Johannesburg, South Africa: Centre for Policy Studies. Retrieved May 28, 2013, from www.cps.org.za.

Peet, R.(2004). Modern Geographical Thought (pp. 247-260). Oxford, UK: Blackwell.

Rajivan, A. K. (1999). Policy Implications for Gender Equity: The India Time Use Survey, 1998-1999 (pp. 03-11). Ahmedabad: International Seminar on Time Use Surveys. Retrieved June 21, 2016.

Raju, S. (n.d.). Engendering the Androcentric Discipline of Geography and Claiming a Place: Revisiting the (Un) Familiar. In Doing Gender 
Doing Geography (pp. 18-20).New Delhi: Women in Politics in South Asia (pp. 199-213). Routledge. New Delhi: Mangalam Publications.

Rizvi, S. H. (2006). Empowering Women through Reservation in Urban Local BodiesDifference Between Theory and Practice. In Empowerment of Women in Urban Administration (Experiences and Strategies) (pp. 193-211). New Delhi: Serials Publications.

Ruet, J., \& Lama-Rewal, S. T. (2009).Governing India's Metropolises. New Delhi: Routledge.

Sathe, D., Klasen, S., Priebe, J., \& Biniwale, M. (2013).Can the Female Sarpanch Deliver? Economic and Political Weekly, XLVIII (11), 5057. Retrieved March 22, 2013, from www.epw.in.

Singh, S. K. (2006). Women Empowerment in India: Emerging Leadership in Urban U.P. In Empowerment of Women in Urban Administration (Experiences and Strategies) (pp. 61-64). New Delhi: Serials Publications.

Srivastava, D. N. (n.d.).Political Status of Indian The Community GPI Survey (Part II). (n.d.). Retrieved December 31, 2014, from GPI Atlantic website: www.gpiatlantic.org/pdf/communitygpi/comm unitypart2g.pdf

Time Use Surveys, T. (2013).Guidelines for Harmonising Time Use Surveys (pp. 06-20, Rep. No. 22).Luxembourg: United Nations Economic Commission for Europe. Retrieved December 24, 2014.

UNDP. (1995). Human Development Report: Gender and Human Development (Publication). New Delhi: Oxford University Press.

Upadhyay, K. K., \& Bhardwaj, P. (2006).The Gender Paradigm in Local Governance: Indian Experience. In Empowerment of Women in Urban Administration (Experiences and Strategies) (pp. 130-148). New Delhi: Serials Publications.

Women: Progress since Independence. In 